\title{
Growth and Yield Performance of Irrigated Lowland Rice NSIC Rc218 (Oryza sativa L.) as Influenced by Water and Fertilizer Applications
}

\author{
Ulysses A. Cagasan ${ }^{1}$ and Nemesio V. Tamayo ${ }^{2}$ \\ ${ }^{1}$ Department of Agronomy, Visayas State University, Baybay City, Leyte 6521-A, \\ Philippines and ${ }^{2}$ Department of Crop Science, College of Agriculture, Central \\ Luzon State University, Science City of Muñoz, Nueva Ecija
}

\section{ABSTRACT}

For better rice productivity there is a need to address the problems on water shortage and nutrient management. This study was conducted to evaluate the growth and yield performance and the interaction effect between water and fertilizer applications on irrigated lowland rice (NSIC Rc218); to determine the relationships of other plant characters which are contributory to yield; and to assess the cost and return of irrigated lowland rice production $\mathrm{ha}^{-1}$ as influenced by water and fertilizer applications.

Two methods of water application were evaluated and results showed that alternate wet and dry methods (AWD) were able to save $19.02 \%$ of the total water received by the rice plants compared to continuous flooded condition. Grain yield of irrigated lowland rice (NSIC Rc218) was significantly $(p<0.05)$ increased by $1.84 \mathrm{t} \mathrm{ha}^{-1}$ which is higher by $35 \%$ when applied with recommended inorganic fertilizer at the rate of 100-60-60 kg $\mathrm{N}, \mathrm{P}_{2} \mathrm{O}_{5}$ andK $\mathrm{K}_{2} \mathrm{ha}^{-1}\left(\mathrm{~T}_{2}\right)$ than that of unfertilized plants $\left(\mathrm{T}_{1}\right)$.

Correlation analysis showed that grain yield is positively correlated to the number of productive tillers panicle ${ }^{-1}$, panicle length $(\mathrm{cm}), \%$ filled spikelet panicle ${ }^{-1}$, weight of 1000 grains (g) and LAI but not on the number of spikelets panicle- ${ }^{1}$. Plants applied with 100-60-60 kg N, $\mathrm{P}_{2} 0_{5}$ and $\mathrm{K}_{2} 0 \mathrm{ha}^{-1}$ $\left(\mathrm{T}_{2}\right)$ and those applied with 75\% RRIF $+25 \%$ RRVC $\left(\mathrm{T}_{4}\right)$ generated the highest net income of PhP 66,915.00 ha and PhP 60,440.00 ha ${ }^{-1}$ respectively, than unfertilized plants of $\mathrm{PhP} 40,375.00 \mathrm{ha}^{-1}$.

Keywords: Flooded, AWD, water and fertilizer applications, performance and fertilizer

\section{INTRODUCTION}

Rice (Oryza zativa L.) is one of the most important staple foods and sources of livelihood among rice farmers not only in Eastern Visayas but also in some rice growing areas in Southeast Asia IRRI (2011). Rice not only fulfills the nutritional needs of human beings but also possesses

Correspondence: U. A. Cagasan Address: Department of Agronomy, Visayas State University, Baybay City, Leyte 6521-A, Philippines Tel No.: +63-053-563-7636; E-mail: uly_cagasan@yahoo.com DOI: $10.32945 /$ atr3826.2016 
several medicinal properties and therapeutic values. The Food and Agriculture Organization (FAO) reported that the world rice consumption in 2013-2014 was around 475.5 million tons, but it is expected to increase to 489.4 million tons in 2015-2016 (Rice Global Production, 2015).

Irrigated lowland rice like NSIC Rc218 developed by PhilRice is considered special rice because it has high sensory preference and acceptability as it is tender and tastier than the other common rice varieties (PhilRice, 2013). However, its yield potential cannot cope with the present demand, so there is a need to find ways to increase its production. Among the numerous ways to increase production are to improve the cultural management practices such as the fertilizer and water applications. To address this problem, new methods of irrigation are urgently needed to save water and sustain good yield of rice (Tuong and Bouman, 2002). A number of studies have shown that intermittent flooding to keep the soil saturated provides better water-use efficiency (Ratilla and Cagasan, 2011). The study of Hamora and Agustin (2014) revealed that the continuous use of organic and inorganic sources of nutrients had positive effects on the growth and yield performance of lowland rice. However, there is still lack of information on how the kind of fertilizer (organic, inorganic or a combination of the two) will influence the growth and yield of a particular rice/variety under different water applications (flooded and alternate wetting and drying (AWD).

Thus, this study was conducted to evaluate the growth and yield performance of irrigated lowland rice (NSIC Rc218) as influenced by water and fertilizer applications; to determine the interactions between water and fertilizer applications on all parameters gathered; to determine the relationships of other plant characters which are contributory to yield; and asses the cost and return analysis of irrigated lowland rice production ha- ${ }^{1}$ as influenced by water and fertilizer applications.

\section{MATERIALS AND METHODS}

The experiment was laid out in split plot arranged in a Randomized Complete Block Design (RCBD) with three replications. Water applications $\left(\mathrm{WA}_{1}\right.$ - Flooded and $\left.\mathrm{WA}_{2}-\mathrm{AWD}\right)$ were designated as the main plot, while fertilizer applications ( $\mathrm{T}_{1}$ - No fertilizer application as control, $\mathrm{T}_{2}-100-60$ $60 \mathrm{~kg} \mathrm{~N}, \mathrm{P}_{2} \mathrm{O}_{5}$ and $\mathrm{K}_{2} 0$ ha- ${ }^{1}$ Recommended Rate of Inorganic Fertilizer (RRIF), $\mathrm{T}_{3}$-Vermicast at $10 \mathrm{t} \mathrm{ha}^{-1}$ Recommended Rate of Vermicast (RRVC), $\mathrm{T}_{4}-75 \%$ $\mathrm{RRIF}+25 \%$ RRVC, $\mathrm{T}_{5}-50 \% \mathrm{RRIF}+50 \% \mathrm{RRVC}$ and $\mathrm{T}_{6}-25 \% \mathrm{RRIF}+75 \%$ RRVC) were designated as the subplot.

Before transplanting the rice seedlings, ten (10) soil samples were collected at random from the experimental area at a depth of $0-20 \mathrm{~cm}$. After harvest, five soil samples were also collected from each treatment plot. These were composited, air-dried, pulverized and sieved using a 2-mm 
wire mesh. Soil $\mathrm{pH}$ was measured potentiometrically in soil/solution suspensions of 1:2:5 $\mathrm{H}_{2} \mathrm{O}$. The organic carbon content was determined using Walkley-Black method, while the available P was determined using Bray No. 2 method. Exchangeable K, particle size distribution (analyzed using the hydrometer method), and water holding capacity were all determined following the methods described in a handbook on 'Standard Methods of Analysis for Soil, Plant Tissue, Water and Fertilizer' prepared by PCARRD (1980).

Vermicast organic fertilizer and inorganic fertilizer were used in this study. The vermicast was obtained from Organic Diversified Integrated Farming System (ODIFS), VSU, Baybay City, Leyte. Full amount of vermicast in treatments 3 to $6\left(\mathrm{~T}_{3}-\mathrm{T}_{6}\right)$ were applied five days before planting. Whole amount of $\mathrm{P}_{2} 0_{5}, \mathrm{~K}_{2} \mathrm{O}$ and half of $\mathrm{N}$ fertilizers required were applied in all treatment plots immediately before planting by broadcasting and incorporating it into the soil. The remaining half of $\mathrm{N}$ was top-dressed forty (40) days after transplanting. The different water applications were applied seven days after transplanting. For $\mathrm{WM}_{1}$ (Flooded) the area was continuously flooded at a depth of two to four $\mathrm{cm}$ up to maximum tillering stage. This was increased to a depth of five to seven $\mathrm{cm}$ until reproductive stage. Two weeks before harvest, the whole area was drained to facilitate harvesting operation.

For $\mathrm{WM}_{2}(\mathrm{AWD})$, the area was irrigated when the field starts to dry up and partially crack or the rice plants showed early sign of wilting as manifested by curling of the young leaves. This was observed during the hottest hour of the day. The field was irrigated right away because rice plants experienced water stress once signs of wilting were observed. Irrigation was done by allowing the entry of water just enough to keep the soil moist. Irrigation water from the river banks served as the source of water in all the rice fields in the area. This was done by maintaining the flow/current of water from the main canal before application to the experimental plots. Drainage canal was constructed to drain the excess water from designated plots during rainy days. Plastic lining around the treatment plots was installed along the levees to control water seepage and contamination among treatment plots.

All the recommended cultural management practices for rice production were strictly followed from land preparation up to harvesting and processing.

\section{Data Gathered}

The parameters evaluated for this study were the total amount of water received by the rice plant $\left(\mathrm{m}^{3}\right.$ ha- $\left.{ }^{1}\right)$ and the agronomic characteristics such as the number of days from transplanting to heading and maturity; plant height $(\mathrm{cm})$ at harvest; fresh straw yield $\left(\mathrm{t} \mathrm{ha}^{-1}\right)$ and leaf area index (LAI). For the yield and yield component characteristics, the following parameters were measured such as the number of productive tillers hill ${ }^{-1}$, 
number of filled grains per panicle, number of unfilled grains per panicle, weight of 1,000 grains $(\mathrm{g})$ and total grain yield $\left(\mathrm{t} \mathrm{ha} \mathrm{H}^{-1}\right)$. Harvest index was calculated as the ratio of the economic yield and biological yield while initial and final soil analyses and production cost and return were also computed.

\section{RESULTS AND DISCUSSION}

\section{Agronomic Characteristics}

The agronomic characteristics of irrigated lowland rice (NSIC Rc218) as influenced by water and fertilizer applications are presented in Table 1.

All agronomic characteristics were significantly affected by the water application except on straw weight. Plants grown under flooded condition significantly $(p<0.05)$ matured late, grew taller with broader leaf area, but low number of tillers hill ${ }^{-1}$ than those plants grown in AWD condition. The significant variation observed in the growth and maturity of the rice plant can be attributed to several environmental factors such as soil, nutrients, water and agro-climatic conditions. This indicates that rice plants perform better under continuous flooding which resulted in increased plant height and leaf area index. Flooded condition enhanced softness of the soil that provided good physicochemical changes favorable for nutrient absorption by the rice plants.

Table 1. Growth characteristics of NSIC Rc218 as influenced by water and fertilizer applications, DS 2014, Baybay City, Leyte

\begin{tabular}{|c|c|c|c|c|c|}
\hline Treatments & $\begin{array}{c}\text { Number } \\
\text { of days to } \\
\text { maturity }\end{array}$ & $\begin{array}{l}\text { Plant } \\
\text { height } \\
(\mathrm{cm})\end{array}$ & $\begin{array}{c}\text { Leaf } \\
\text { area } \\
\text { index }\end{array}$ & $\begin{array}{c}\text { Number } \\
\text { of tillers } \\
\text { hill }^{-1}\end{array}$ & $\begin{array}{c}\text { Straw } \\
\text { weight } \\
\left(\mathrm{t} \mathrm{ha}^{-1}\right) \\
\end{array}$ \\
\hline \multicolumn{6}{|l|}{ Water Applications } \\
\hline $\mathrm{WM}_{1}=$ Flooded & $111.70^{\mathrm{a}}$ & $109.65^{\mathrm{a}}$ & $3.74^{\mathrm{a}}$ & $15.12^{\mathrm{b}}$ & 6.47 \\
\hline $\mathrm{WM}_{2}=\mathrm{AWD}$ & $110.00^{\mathrm{b}}$ & $103.73^{b}$ & $3.15^{\mathrm{b}}$ & $16.52^{\mathrm{a}}$ & 6.08 \\
\hline HSD 0.05 & $* *$ & $* *$ & $* *$ & $*$ & ns \\
\hline \multicolumn{6}{|l|}{ Fertilizer Application } \\
\hline $\mathrm{T}_{1}=$ No fertilizer (Control) & $109.50^{c}$ & $95.48^{\mathrm{e}}$ & $2.07^{\mathrm{d}}$ & $13.73^{\mathrm{cd}}$ & $4.91^{\mathrm{c}}$ \\
\hline $\begin{aligned} \mathrm{T}_{2}= & 100-60-60 \mathrm{~kg} \mathrm{~N}, \mathrm{P}_{2} 0_{5} \\
& \text { and } \mathrm{K}_{2} 0 \mathrm{ha}^{-1}(\mathrm{RRIF})\end{aligned}$ & $112.50^{\mathrm{a}}$ & $117.60^{\mathrm{a}}$ & $5.12^{\mathrm{a}}$ & $20.00^{\mathrm{a}}$ & $7.88^{\mathrm{a}}$ \\
\hline $\begin{array}{c}\mathrm{T}_{3=}=\text { Vermicast } 10 \mathrm{tha}^{-1} \\
\text { (RRVC) }\end{array}$ & $109.50^{c}$ & $99.40 \mathrm{~d}^{\mathrm{e}}$ & $2.37^{\mathrm{d}}$ & $12.46^{\mathrm{d}}$ & $4.59^{\mathrm{c}}$ \\
\hline $\mathrm{T}_{4}=75 \% \mathrm{RRIF}+25 \% \mathrm{RRVC}$ & $112.50^{\mathrm{a}}$ & $114.20^{\mathrm{ab}}$ & $4.28^{\mathrm{ab}}$ & $17.70^{\mathrm{ab}}$ & $7.47^{\mathrm{ab}}$ \\
\hline $\mathrm{T}_{5}=50 \% \mathrm{RRIF}+50 \% \mathrm{RRVC}$ & $110.50^{\mathrm{b}}$ & $109.80^{\mathrm{bc}}$ & $3.72^{\mathrm{bc}}$ & $16.70^{\mathrm{bc}}$ & $6.53^{\mathrm{bc}}$ \\
\hline $\mathrm{T}_{6=}=25 \%$ RRIF $+75 \%$ RRVC & $110.50^{\mathrm{b}}$ & $103.70^{\mathrm{dc}}$ & $3.10^{\mathrm{dc}}$ & $14.30^{\mathrm{cd}}$ & $5.26^{\mathrm{c}}$ \\
\hline$H S D 0.05$ & $* *$ & $* *$ & $*$ & $* *$ & $* *$ \\
\hline
\end{tabular}

Means with the same letter in a columns and rows are not significantly different at $5 \%$ level, HSD.

Moreover, Bouman et al. (2007) mentioned that flooded condition also offers a kind of temperature control for the rice crop. On hot days the waterfilled fields keep the rice plants cool, and warm them on cool nights. Flooded condition helps in preventing excessive salt accumulation and soil 
depletion thus enhances nutrient uptake and absorption by plants resulting in taller and more vigorous plants.

On the other hand, the number of tillers per hill was significantly $(p<0.05)$ higher under AWD than under flooded condition. Aslam and Horinkova (2002) found that the better gas exchange between soil and air leads to better aeration in soil medium under AWD condition that consequently resulted to a more favorable development of young shoots and higher number of tillers produced per hill. Moreover, according to Aslam et al. (2002), drying the field can reduce the toxicity of organic and inorganic toxins that accumulate from the decomposition of organic materials at the beginning of the cropping season, thus leading to favorable development of young shoots and to more tillers.

Fertilizer application significantly affected all the agronomic characteristics of irrigated lowland rice (NSIC Rc218) such as the number of days to maturity, plant height, straw yield ha ${ }^{-1}$, leaf area index and number of tillers hill $^{-1}$. Rice plants applied with inorganic fertilizer at the rate of 100-60-60 kg N, $\mathrm{P}_{2} \mathrm{O}_{5}$ and $\mathrm{K}_{2} 0 \mathrm{ha}^{-1}$ and those with 75\% RRIF $+25 \%$ RRIF grew vigorously with broader leaf area, taller plants and produce more tillers hill ${ }^{-1}$ resulting in heavy straw weight. They matured later than those plants applied with low rates of RRIF at 25\% and 50\%, vermicast at $10 \mathrm{t} \mathrm{ha}^{-1}$ and plants without fertilization. Increasing the application of inorganic fertilizer delayed the maturity of rice plants but caused taller plants compared to those applied with vermicast and without fertilizer. Moreover, treatments with higher amount of inorganic fertilizer showed positive response to agronomic parameters such as plant height, leaf area index, number of tiller hill $^{-1}$ and straw weight $\mathrm{t} \mathrm{ha}{ }^{-1}$. These results correlated to the findings of Hamora and Agustin (2014) which showed that most of the agronomic characteristics of rice were significantly affected by inorganic fertilizer hence, resulted in taller plants with broader leaf area index, more number of tiller hill ${ }^{-1}$ and heavier straw weight. According to Bouman et al. (2007) plant height is increased significantly due to nitrogen application which enhances physiological processes such as cell division and cell elongation. However, Haby et al. (2012) reported that high amount of $\mathrm{N}$ promotes development of above ground parts of the plant caused by high assimilates formation during photosynthates that leads to increased plant heights but delayed flowering as well as maturity of the rice plant.

\section{Yield, Yield Components and Harvest Index}

The yield and yield components as well as harvest index of irrigated lowland rice (NSIC Rc218) as influenced by water and fertilizer applications are presented in Table 2 . Among the rice yield parameters gathered, only panicle length $(\mathrm{cm})$ and number of filled grains panicle ${ }^{-1}$ were significantly $(p<0.05)$ affected by water application. However, under fertilizer treatments yield and other yield components were significantly 
affected except harvest index.

It was noted that rice plants under flooded conditions developed longer panicles with more number of filled spikelet than plants subjected to AWD condition. This result was attributed to the presence of enough moisture that enhanced nutrient absorption by the rice plants resulting in vigorous growth as evidenced by an increased plant height and leaf area index (Table 1). This study supports the findings of Maclean et al. (2002) showing that development of higher number of filled grains per panicle with lower percent spikelet sterility when enough water was made available specifically during panicle initiation stage. However, Ratilla and Cagasan (2011) observed that conventional irrigation led to the production of longer panicles and more filled grains per panicle but did not cause significant $(p<0.05)$ increase in yield of irrigated lowland rice. This result confirmed the finding of Bouman et al. (2007) that in rice production it does not need more water or total plant submergence throughout the growing period to have good crop yield.

On the other hand, irrigated lowland rice (NSIC Rc218) responded significantly $(p<0.05)$ in all yield components to different fertilizer applications. Treatments applied with RRIF at the rate of $100-60-60 \mathrm{~kg} \mathrm{~N}$, $\mathrm{P}_{2} \mathrm{O}_{5}$ and $\mathrm{K}_{2} 0$ ha $^{-1}$ significantly produced more productive tillers plant ${ }^{-1}$, longer panicle length, more number and high percent filled spikelets as well as heavier weight of 1000 grains thus resulting in higher total grain yield. However, it was statistically similar to those treatments applied with $75 \%$ RRIF + 25\% RRVC and 50\% RRIF + 50\% RRVC. Result further that inorganic fertilizer is a contributory factor to the showed yield component for rice production. Nutrients from pure inorganic fertilizer at the rate of 100-60-60 kg N, $\mathrm{P}_{2} \mathrm{O}_{5}$ and $\mathrm{K}_{2} \mathrm{O}$ ha $^{-1}, 75 \% \mathrm{RRIF}+25 \% \mathrm{RRVC}$ and $50 \% \mathrm{RRIF}+$ $50 \%$ RRVC provided sufficiently the nutrient requirement of rice plant during grain formation and filling. On the other hand, the lowest yields were noted in treatments applied with vermicast at $10 \mathrm{t} \mathrm{ha}^{-1}\left(\mathrm{~T}_{3}\right), 25 \%$ RRIF $+75 \%$ RRVC $\left(\mathrm{T}_{6}\right)$ and unfertilized plants $\left(\mathrm{T}_{1}\right)$. These results were due to the slow release and insufficient amount of nutrients from treatments applied with full amount of organic fertilizer vermicast, $25 \%$ RRIF + 75\% RRVC and plants not applied with fertilizer $\left(\mathrm{T}_{1}\right)$. Stoop et al. (2002) mentioned that nitrogen requirement for grain development is very significant because during the process of spikelet formation, some of the differentiated spikelets degenerate. Degeneration occurs at the stage of reduction division of pollen mother cells resulting in high sterility thus affecting the development and filling of spikelets causing a low number of filled grains per panicle ${ }^{-1}$.

Substantial differences were observed on the interaction effect between water and fertilizer applications (Table 3). Plants applied with RRIF and RRVC $\left(\mathrm{T}_{2}-\mathrm{T}_{6}\right)$ significantly $(p<0.05)$ obtained heaviest weight of 1000 grains (gms) both in flooded and AWD conditions. A significant lightest 1000 grain weight (gms) was observed from unfertilized treatment plants. 
Table 2. Yield, yield components and harvest index of NSIC Rc218 as influenced by water and fertilizer applications, DS 2014, Baybay City, Leyte

\begin{tabular}{|c|c|c|c|c|c|c|c|}
\hline Treatments & $\begin{array}{l}\text { Productive } \\
\text { tillers hill-1 }\end{array}$ & $\begin{array}{l}\text { Panicle } \\
\text { length } \\
(\mathrm{cm})\end{array}$ & $\begin{array}{c}\text { No. of filled } \\
\text { spikelet } \\
\text { panicle }^{-1}\end{array}$ & $\begin{array}{c}\text { Percentage } \\
\text { filled spikelet } \\
\text { panicle }^{-1}\end{array}$ & $\begin{array}{l}\text { Weight } \\
\text { of } 1,000 \\
\text { grains }(\mathrm{g})\end{array}$ & $\begin{array}{l}\text { Grain } \\
\text { yield } \\
\left(\text { tha }^{-1}\right)\end{array}$ & $\begin{array}{c}\text { Harvest } \\
\text { index } \\
(\mathrm{HI})\end{array}$ \\
\hline \multicolumn{8}{|l|}{ Water Application } \\
\hline $\mathrm{WM}_{1}=$ Flooded & 10.19 & $25.03^{\mathrm{a}}$ & $96.72^{\mathrm{a}}$ & 76.66 & 27.52 & 4.15 & 0.37 \\
\hline $\mathrm{WM}_{2}=\mathrm{AWD}$ & 9.73 & $23.46^{\mathrm{b}}$ & $76.77^{\mathrm{b}}$ & 74.55 & 27.50 & 4.33 & 0.38 \\
\hline HSD 0.05 & $\mathrm{~ns}$ & $* *$ & $* *$ & ns & ns & $\mathrm{ns}$ & $\mathrm{ns}$ \\
\hline \multicolumn{8}{|l|}{ Fertilizer Application } \\
\hline $\mathrm{T}_{1}=$ No fertilizer (Control) & $7.91 \mathrm{c}$ & $21.83^{c}$ & $72.17^{\mathrm{b}}$ & $70.83^{b}$ & $26.73^{b}$ & $3.34^{\mathrm{b}}$ & 0.36 \\
\hline $\begin{aligned} \mathrm{T}_{2}= & 100-60-60 \mathrm{~kg} \mathrm{~N}, \mathrm{P}_{2} \mathrm{O}_{5}, \\
& \text { and } \mathrm{K}_{2} 0 \mathrm{ha}^{-1}(\mathrm{RRIF})\end{aligned}$ & $11.73^{\mathrm{a}}$ & $26.71^{\mathrm{a}}$ & $95.33^{\mathrm{a}}$ & $80.17^{\mathrm{a}}$ & $29.00^{\mathrm{a}}$ & $5.18^{\mathrm{a}}$ & 0.34 \\
\hline $\mathrm{T}_{3=}$ Vermicast $10 \mathrm{tha}^{-1}$ (RRVC) & $8.50^{\mathrm{bc}}$ & $24.25^{\mathrm{b}}$ & $85.66^{\mathrm{b}}$ & $73.50^{\mathrm{ab}}$ & $29.69^{a}$ & $3.50^{\mathrm{b}}$ & 0.39 \\
\hline $\mathrm{T}_{4}=75 \% \mathrm{RRIF}+25 \% \mathrm{RRVC}$ & $10.90^{\mathrm{a}}$ & $25.01^{\mathrm{ab}}$ & $89.50^{\mathrm{ab}}$ & $79.66^{\mathrm{a}}$ & $28.45^{\mathrm{a}}$ & $5.03^{\mathrm{a}}$ & 0.35 \\
\hline $\mathrm{T}_{5}=50 \% \mathrm{RRIF}+50 \% \mathrm{RRVC}$ & $10.66^{\mathrm{a}}$ & $24.30^{\mathrm{b}}$ & $90.50^{\mathrm{ab}}$ & $73.00^{\mathrm{ab}}$ & $28.05^{\mathrm{a}}$ & $4.53^{\mathrm{a}}$ & 0.37 \\
\hline $\mathrm{T}_{6}=25 \% \mathrm{RRIF}+75 \% \mathrm{RRVC}$ & $10.03^{\mathrm{ab}}$ & $23.38^{\mathrm{bc}}$ & $77.33^{b}$ & $76.50^{\mathrm{ab}}$ & $28.16^{\mathrm{a}}$ & $3.74^{\mathrm{b}}$ & 0.41 \\
\hline$H S D 0.05$ & $* *$ & $* *$ & $* *$ & $* *$ & $* *$ & $* *$ & ns \\
\hline
\end{tabular}

Means with the same letter in a columns and rows are not significantly different at $5 \%$ level, HSD 
$\left(\mathrm{T}_{1}\right)$ under both flooded and AWD conditions. This result is due to a greater amount of nutrients from inorganic fertilizer associated with high solubility and availability when needed by the rice plants. Similarly, vermicast enhanced uptake of nutrients by plants. Soil available nitrogen increased with increasing levels of vermicast and highest nitrogen uptake was obtained resulting in increased filled spikelets and heavier of 1000 grains. On the other hand, unfertilized plants $\left(\mathrm{T}_{1}\right)$ resulted in lightest weight (gms) of 1000 grains regardless of water applications. This result was attributed to the insufficient amount of nutrients particularly phosphorus in soil which is needed for grain-filling formation that greatly affects the grain weight.

Table 3. Weight of 1000 grains (gms) of NSIC Rc218 as influenced by the interaction between water and fertilizer applications, DS 2014, Baybay City, Leyte

\begin{tabular}{lccc}
\hline Fertilizer Application & \multicolumn{2}{c}{ Water Application } & \multirow{2}{*}{ Mean } \\
\cline { 2 - 3 } & Flooded & AWD & \\
\hline $\mathrm{T}_{1}=$ No fertilizer (Control) & $26.30^{\mathrm{c}}$ & $27.17^{\mathrm{c}}$ & $26.73^{\mathrm{b}}$ \\
$\mathrm{T}_{2}=100-60-60 \mathrm{~kg} \mathrm{~N}^{\mathrm{P}} \mathrm{P}_{2} 0_{5}$, & & & \\
$\quad$ and $\mathrm{K}_{2} 0 \mathrm{ha}^{-1}(\mathrm{RRIF})$ & $29.06^{\mathrm{a}}$ & $28.94^{\mathrm{a}}$ & $29.00^{\mathrm{a}}$ \\
$\mathrm{T}_{3}={\text { Vermicast } 10 \mathrm{t} \mathrm{ha}^{-1}(\mathrm{RRVC})}_{\mathrm{T}_{4}=75 \% \text { RRIF }+25 \% \text { RRVC }}$ & $29.74^{\mathrm{a}}$ & $29.65^{\mathrm{a}}$ & $29.69^{\mathrm{a}}$ \\
$\mathrm{T}_{5}=50 \%$ RRIF $+50 \%$ RRVC & $28.37^{\mathrm{b}}$ & $28.53^{\mathrm{b}}$ & $28.45^{\mathrm{a}}$ \\
$\mathrm{T}_{6}=25 \%$ RRIF $+75 \%$ RRVC & $28.13^{\mathrm{b}}$ & $27.98^{\mathrm{b}}$ & $28.05^{\mathrm{a}}$ \\
\hline Mean & $28.42^{\mathrm{b}}$ & $28.91^{\mathrm{b}}$ & $28.16^{\mathrm{a}}$ \\
\hline
\end{tabular}

Means with the same letter in a column are not significantly different at 5\% level, HSD.

\section{Relationships Between Grain Yield and Yield-Contributing Characters}

Correlation analysis was done to determine the relationship between the yields of irrigated lowland rice (NSIC Rc218) to different yield contributory parameters. Most of the contributory characters for yield were positively correlated to productivity except on the number of spikelet per panicle (Table 4). Productive tillers were highly correlated to yield while, panicle length, percent filled spikelet, weight of 1000 grains (gms) and leaf area index were significantly correlated to the grain yield. These results indicated that the yield components significantly influenced the improvement and production of total grain yield.

Ebrahim (2014) reported that photosynthates absorbed by rice plants are utilized in the improvement of yield and yield characters of irrigated lowland rice for the production of the total grain yield. On the other hand, no association was noted between number of filled spikelets panicle ${ }^{-1}$ and grain yield $t$ ha $^{-1}$. This result indicated that number of spikelets per panicle did not increase the total grain yield of NSIC Rc 218.

The above findings corroborate the report of PhilRice (2011) that different levels of nitrogen, phosphorus and potassium indicated a positive relationship with grain yield, relative to the number of productive tillers, number and percent filled spikelet and 1000-grain weight. 
Table 4. Correlation analysis between grain yield and yield contributing characters of NSIC Rc 218 as influenced by water and fertilizer applications, DS 2014, Baybay City, Leyte

\begin{tabular}{|c|c|c|c|c|c|c|c|}
\hline & $\begin{array}{l}\text { Yield } \\
\left(\mathrm{t} \mathrm{ha}^{-1}\right)\end{array}$ & $\begin{array}{c}\text { No. of } \\
\text { Productive } \\
\text { Tillers hill- }^{1}\end{array}$ & $\begin{array}{l}\text { Panicle } \\
\text { Length } \\
\text { (cm) }\end{array}$ & $\begin{array}{l}\text { Number } \\
\text { of } \\
\text { spikelets } \\
\text { panicles }^{-1}\end{array}$ & $\begin{array}{c}\% \text { Filled } \\
\text { Spikelets } \\
\text { panicle }^{-1}\end{array}$ & $\begin{array}{c}1000 \\
\text { grains } \\
\text { (gms) }\end{array}$ & LAI \\
\hline Yield & 1.000 & & & & & & \\
\hline Productive Tillers hill ${ }^{-1}$ & $0.839 * *$ & 1.000 & & & & & \\
\hline Panicle Length (cm) & $0.652 *$ & $0.779 * *$ & 1.000 & & & & \\
\hline No. of Spikelets panicle- ${ }^{1}$ & $0.119 \mathrm{~ns}$ & $0.169 \mathrm{~ns}$ & $0.522 \mathrm{~ns}$ & 1.000 & & & \\
\hline$\%$ Filled Spikelets panicle ${ }^{-1}$ & $0.614^{*}$ & $0.739 * *$ & $0.787 * *$ & $0.345 \mathrm{~ns}$ & 1.000 & & \\
\hline Wt. of 1000 grains (gms) & $0.856^{* *}$ & $0.747 * *$ & $0.655^{*}$ & $0.185 \mathrm{~ns}$ & $0.464 \mathrm{~ns}$ & 1.000 & \\
\hline LAI & $0.859 * *$ & $0.945 * *$ & $0.86 * *$ & $0.324 \mathrm{~ns}$ & $0.767 * *$ & $0.80 * *$ & 1.00 \\
\hline $\begin{array}{l}\mathrm{r} \text { tab0.05 }=0.811 \\
\mathrm{r} \text { tab0.01 }=0.917\end{array}$ & & & & $\begin{array}{l}\mathrm{ns} \\
*_{-} \mathrm{s} \\
*_{*}\end{array}$ & $\begin{array}{l}\text { not signi } \\
\text { gnificant } \\
\text { Highly po }\end{array}$ & $\begin{array}{l}\text { ant, } \\
\text { orrelati } \\
\text { tive co }\end{array}$ & lation \\
\hline
\end{tabular}

\section{Soil Chemical Properties}

Results of initial soil analysis showed that the soil had a pH of 5.51 with $4.61 \% \mathrm{OM}, 0.24 \%$ total $\mathrm{N}, 1.78 \%$ available $\mathrm{P}$ and $41.27 \mathrm{mg} \mathrm{kg}$ exchangeable $\mathrm{K}$ (Table 5). These indicated that the soil was strongly acidic with adequate amount of organic matter and medium amount of total $\mathrm{N}$, low available P and deficient exchangeable K (PCARR, 1980).

Table 5. Soil chemical properties before planting and after harvest of NSIC Rc218 as influenced by water and fertilizer applications

\begin{tabular}{|c|c|c|c|c|c|}
\hline Treatment & Soil pH & $\begin{array}{c}\text { Organic } \\
\text { matter } \\
(\%)\end{array}$ & $\begin{array}{c}\text { Total } \\
\mathrm{N} \\
(\%)\end{array}$ & $\begin{array}{c}\text { Available } \\
\mathrm{P} \\
\left(\mathrm{mg} \mathrm{kg} \mathrm{k}^{-1}\right)\end{array}$ & $\begin{array}{c}\text { Exchange- } \\
\text { able K } \\
\left(\mathrm{mg} \mathrm{kg}^{-1}\right)\end{array}$ \\
\hline Initial Soil Analysis & 5.45 & 4.61 & 0.29 & 1.78 & 41.27 \\
\hline \multicolumn{6}{|l|}{ Final Soil Analysis } \\
\hline \multicolumn{6}{|l|}{ Water Management } \\
\hline $\mathrm{WM}_{1}=$ Flooded & $5.75 \mathrm{a}$ & 4.14 & 0.24 & 1.15 & $54.84 \mathrm{a}$ \\
\hline $\mathrm{WM}_{2}=\mathrm{AWD}$ & $5.34 b$ & 4.27 & 0.24 & 1.16 & $48.26 \mathrm{~b}$ \\
\hline$H S D 0.05$ & $*$ & ns & ns & ns & $*$ \\
\hline \multicolumn{6}{|l|}{ Fertilizer Management } \\
\hline $\mathrm{T}_{1}=$ No fertilizer (Control) & 5.55 & 4.02 & 0.22 & $0.78 b$ & $44.99 b$ \\
\hline $\begin{array}{c}\mathrm{T}_{2}=100-60-60 \mathrm{~kg} \mathrm{~N}, \mathrm{P}_{2} \mathrm{O}_{5}, \mathrm{~K}_{2} 0 \\
\left.\mathrm{ha}^{-1} \mathrm{RRIF}\right)\end{array}$ & 5.53 & 4.09 & 0.25 & $1.13 \mathrm{ab}$ & $77.26 \mathrm{a}$ \\
\hline $\mathrm{T}_{3}=$ Vermicast $10 \mathrm{tha}^{-1}$ (RRVC) & 5.68 & 4.53 & 0.26 & $1.17 \mathrm{ab}$ & $49.96 b$ \\
\hline $\mathrm{T}_{4}=75 \% \mathrm{RRIF}+25 \% \mathrm{RRVC}$ & 5.48 & 4.29 & 0.24 & $1.40 \mathrm{a}$ & $60.50 \mathrm{a}$ \\
\hline $\mathrm{T}_{5}=50 \% \mathrm{RRIF}+50 \% \mathrm{RRVC}$ & 5.49 & 4.19 & 0.25 & $1.26 \mathrm{ab}$ & $43.47 \mathrm{~b}$ \\
\hline $\mathrm{T}_{6}=25 \% \mathrm{RRIF}+75 \% \mathrm{RRVC}$ & 5.58 & 4.14 & 0.26 & $1.18 \mathrm{ab}$ & $44.12 b$ \\
\hline HSD 0.05 & ns & ns & ns & $*$ & $*$ \\
\hline
\end{tabular}

Means within column followed by the same letter are not significantly different at $5 \%$ level, HSD. Soil Chemical Properties was analyzed at Central Services Laboratory, VSU, Visca, Baybay City, Leyte.

In the final soil analysis done after harvest, it was found that soil $\mathrm{pH}$ and exchangeable K were significantly $(p<0.05)$ affected by water application. Specifically, the value of exchangeable $\mathrm{K}\left(\mathrm{mg} \mathrm{kg}^{-1}\right)$ significantly increased to 13.57. The soil $\mathrm{pH}$ under flooded condition, also increased to 0.30 indicating that the soil $\mathrm{pH}$ changed towards neutral after the soil's being exposed to continued submergence in water. 
In contrast, the amount of $\mathrm{OM}$, total $\mathrm{N}$ and available $\mathrm{P}$ were not significantly $(p<0.05)$ affected by water application (Table 5$)$. Regarding the effects of fertilizer application, results of the final soil analysis showed that only available $\mathrm{P}\left(\mathrm{mg} \mathrm{kg}^{-1}\right)$ and exchangeable $\mathrm{K}\left(\mathrm{mg} \mathrm{kg}^{-1}\right)$ were significantly influenced by fertilizer treatments (Table 5). The amounts of organic matter $(\% \mathrm{OM})$ and nitrogen $(\%$ total $\mathrm{N})$ in the soil also decreased after rice was planted. These results could be attributed to crop removal and some of the nutrients were lost through runoff brought about by heavy rains and during irrigation.

\section{Amount of Water Received by the Rice Plants}

The total amount of water received by rice plants throughout the growing period was $15,349 \mathrm{~m}^{3} \mathrm{ha}^{-1}$ under flooded condition and $12,431 \mathrm{~m}^{3}$ $\mathrm{ha}^{-1}$ under AWD (Table 6). These amounts of water came from the rain $(9,020 \mathrm{~m} 3)$ and from the irrigation water added to the field $(6,329 \mathrm{~m} 3)$ in flooded plots and $(3,411 \mathrm{~m} 3)$ in the AWD plots. Data shows that under AWD application, the amount of irrigation water added to the field was only $53 \%$ of the irrigation water. This means that AWD water application was able to save $47 \%$ of irrigation water without affecting the crop yield.

Table 6. Total amount of water received by the rice plant (supplied and from the rain) in the field $\mathrm{m}^{3}$ ha ${ }^{-1}$ from land preparation up to $2^{\text {nd }}$ week before harvesting of NSIC Rc218

\begin{tabular}{lccc}
\hline Treatments & $\begin{array}{c}\text { Amount of water } \\
\text { from the rain } \\
\left(\mathrm{m}^{3} \mathrm{ha}^{-1}\right)\end{array}$ & $\begin{array}{c}\text { Amount of water } \\
\text { from irrigation } \\
\left(\mathrm{m}^{3} \mathrm{ha}^{-1}\right)\end{array}$ & $\begin{array}{c}\text { Total water } \\
\text { received by the } \\
\text { rice plant }\left(\mathrm{m}^{3} \mathrm{ha}^{-1}\right)\end{array}$ \\
\hline $\mathrm{WM}_{1}$ Flooded & 9,020 & 6,329 & 15,349 \\
$\mathrm{WM}_{2}$ AWD & 9,020 & 3,411 & 12,431 \\
\hline $\begin{array}{c}\text { Difference on water } \\
\text { applied to the field }\end{array}$ & $53.89 \%$ & $80.98 \%$ \\
Amount of water saved & $46.11 \%$ & $19.02 \%$ \\
\hline
\end{tabular}

\section{Cost and Return Analysis}

Results revealed that plants grown under flooded condition produced a net income of $\mathrm{PhP} 38,808 \mathrm{ha}^{-1}$ and $\mathrm{PhP} 38,838 \mathrm{ha}^{-1}$ for AWD condition (Table 7). On the other hand, fertilizer treatments applied with 100-60-60 $\mathrm{kg} \mathrm{N}, \mathrm{P}_{2} \mathrm{O}_{5} \& \mathrm{~K}_{2} \mathrm{O}$ ha $^{-1}$ (RRIF) generated the highest net income of $\mathrm{PhP}$ $66,915.00 \mathrm{ha}^{-1}$ and treatments applied with 75\% RRIF + 25\% RRVC PhP $60,440.00 \mathrm{ha}^{-1}$, followed by treatments without fertilizer application $\mathrm{PhP}$ 40,375.00 ha ${ }^{-1}, 50 \%$ RRIF + 50\% RRVC PhP 39,215.00 ha ${ }^{-1}$ and 25\% RRIF + $75 \%$ RRVC PhP 25,257.00 ha ${ }^{-1}$. Variations on the net income from different treatments were due to low yield under treatments without fertilization and treatments applied with pure vermicast and 75\% RRVC. Also the cost of purchasing vermicast and labor in hauling and application added to the 
cost of production, thus resulted in a negative net income of PhP11, 265.00 ha $^{-1}$.

Table 7. Cost and return analysis of NSIC Rc218 rice production ha ${ }^{-1}$ as influenced by water and fertilizer applications, DS 2014, Baybay City, Leyte

\begin{tabular}{lcccc}
\hline \multicolumn{1}{c}{ Treatments } & $\begin{array}{c}\text { Grain } \\
\text { Yield } \\
\left(\mathrm{kg} \mathrm{ha}^{-1}\right)\end{array}$ & $\begin{array}{c}\text { Gross } \\
\text { Income } \\
\left(\text { PhP ha }^{-1}\right)\end{array}$ & $\begin{array}{c}\text { Production Cost } \\
\left(\text { PhP ha }^{-1}\right)\end{array}$ & $\begin{array}{c}\text { Net } \\
\text { Income } \\
\left(\text { PhP ha }^{-1}\right)\end{array}$ \\
\hline $\begin{array}{l}\text { Water Management } \\
W_{1}=\text { Flooded }\end{array}$ & 4,150 & 87,150 & 48,342 & 38,808 \\
$W_{2}=$ AWD & 4,330 & 90,930 & 52,092 & 38,838 \\
\hline Fertilizer Management & & & & \\
$\mathrm{T}_{1}=$ No fertilizer (Control) & 3,340 & 70,140 & 29,765 & $40,375.00$ \\
$\mathrm{~T}_{2}=$ 100-60--60 kg N, $\mathrm{P}_{2} 0_{5} \&$ & & & & \\
$\quad$ K 0 ha-1 (RRIF) & 5,180 & 108,780 & 41,865 & $66,915.00$ \\
$\mathrm{~T}_{3}=$ Vermicast 10 t ha-1 (RRVC) & 3,500 & 73,500 & 84,765 & $-11,265.00$ \\
$\mathrm{~T}_{4}=75 \%$ RRIF + 25\% RRVC & 5,030 & 105,630 & 45,190 & $60,440.00$ \\
$\mathrm{~T}_{5}=50 \%$ RRIF + 50\% RRVC & 4,530 & 95,130 & 55,915 & $39,215.00$ \\
$\mathrm{~T}_{6}=$ 25\% RRIF + 75\% RRVC & 3,740 & 81,060 & 55,803 & $25,257.50$ \\
\hline
\end{tabular}

Current price for dried palay in Leyte $=\mathrm{PhP} 21.00 / \mathrm{kg}$

The potential, positive contribution of vermicast to any yield through the improving physical properties of soil that cannot be accounted for since this study was done only for one cropping.

\section{CONCLUSIONS}

1. Plants grown under flooded conditions significantly grew taller with broader leaf area and matures later but few number of tillers hill ${ }^{-1}$ but, were not significantly different in terms of yield compared to there plants grown in AWD conditions. Likewise, plants applied with RRIF at the rate of $100-60-60 \mathrm{~kg} \mathrm{~N}, \mathrm{P}_{2} \mathrm{O}_{5}$ and $\mathrm{K}_{2} 0 \mathrm{ha}^{-1}$ significantly produced more productive tillers hill ${ }^{-1}$, longer panicle length, more number and high percent filled grains panicle ${ }^{-1}$ and heavier weight of 1000 grains (gms) resulted in higher total grain yield in $\mathrm{t} \mathrm{ha}^{-1}$ relative to the untreated plants.

2. Only the weight of 1000 grains showed a significant interaction effect between water and fertilizer applications of irrigated lowland rice NSIC Rc218;

3. A positive correlation was noted between yield and other yield contributory characters of irrigated lowland rice NSIC Rc218 except on the number of spikelets panicle ${ }^{-1}$. Productive tillers were highly correlated to yield while panicle length, percent filled spikelet per panicle, weight of 1000 grains (g) and leaf area index were significantly correlated to yield. 
4. No significant differences on the net income per hectare of irrigated lowland rice NSIC Rc218 under two water applications were found. Plants applied with RRIF 100-60--60 kg N, $\mathrm{P}_{2} \mathrm{O}_{5} \& \mathrm{~K}_{2} 0 \mathrm{ha}^{-1}$ generated the highest net income of PhP 66,915.00 ha'.

\section{RECOMMENDATIONS}

1. To save a substantial amount of water, it is recommended that irrigated lowland rice be grown under AWD water system to maintain the soil at moist condition and should be sprayed with pre-emergence herbicides once to minimize the presence of weeds as well as the cost of weeding.

2. Further study needs to be conducted in areas where dry season is very pronounced like in the province of Nueva Ecija.

3. Likewise, another study maybe conducted with more cropping to verify further the effects of the vermicast organic fertilizer in improving the soil properties and in enhancing rice productivity.

\section{REFERENCES}

ASLAM, M., QURESHI, A.S. and V.M, HORINKOVA. 2002. Water saving strategies for irrigated rice. Journal of Drainage and Water Management 6(1).

BOUMAN, B. A. M., R. M. LAMPAYAN, and T. P. TUONG. 2007. Water management in irrigated rice: Coping with water scarcity. IRRI, Los Baños, Philippines. www.irri.org/irrc/publications/ water\%20management_1.pdf.

EBRAHIM, A. 2014. Agricultural Science, Takestan Branch, Islamic Azad, University, Takestan, Iran.

HABY V. A., M. L. BAKER, and S. A. FEAGLEY. 2012. Soils and fertilizers. In: Masabni J, Dainello F, Cotner S, editors. Texas Vegetable Growers' Handbook. http://aggie-horticulture.tamu.edu/vegetable/texasvegetable-growers-handbook/chapter-iii-soils-fertilizers/.

HAMORA, J. A. and M. B, AGUSTIN. 2014. Agronomic Efficiency of Inbred and Hybrid Rice Under Different Production Systems and Fertilizer Management Schemes in Aborlan, Palawan. Unpublished dissertation. Central Luzon State University, Science City of Munoz, Neva Ecija, Philippines.

MACLEAN J. L., D. DAWE, B. HARD and G. P. HETTEL. 2002. Rice Almanac. IRRI, Los Baños, Philippines. 253 pp. www.books.google.com. ph/books? isbn-0851996361.

PHILIPPINE RICE RESEARCH INSTITUTE. 2011. Philippine Rice R and D Highlights 2010. Maligaya, Science City of Muñoz, 3119, Nueva Ecija. 
RATILLA, M. D. and U. A. CAGASAN. 2010. Growth and Yield Performance of Selected Lowland Rice Varieties under Alternate Wet and Dry Water Management. Annals of Tropical Research, 28 (23): 2-14.

RICE GLOBAL PRODUCTION. 2015. ww.fao.org/economic/ est/publications/rice-publications/rice-market-monitor-rmm/en.

STOOP. W. A., N. UPHOFF and A. KASSAM. 2002. A review of agricultural research issues raised by the system of rice intensification (SRI) in Madagascar: opportunities for improving farming systems for resource-labor farmers. Agricultural Systems. 71: 249-274. 